\title{
GINGIVEKTOMI SEBAGAI TATALAKSANA GINGIVAL ENLARGEMENT PADA PASIEN PERAWATAN ORTHODONTIK CEKAT
}

\author{
Eka Pramudita Ramadhany \\ Departement Gigi dan Mulut, Fakultas Kedokteran, Universitas Udayana, Denpasar, Bali \\ E-mail: $\underline{\text { drgdhanyramadhany@gmail.com }}$
}

\begin{abstract}
Gingival enlargement is an increase in gingival size which is a common feature of gingival disease. One of the treatment for gingival is gingivectomy. The purpose of deciding gingivectomy is to remove the gingival tissue which is a pocket wall to enhance visibility and accesbility for self cleaning. A 30 years old female patient presents gingiva that appear enlarged in the lower anterior region. The patient has a history of using fixed orthodontic appliances for 2 years. Gingival enlargement is in the right canine to the left canine. Gingivectomy has performed with conventional techniques using a scalpel. Two weeks control results showed satisfactory results where there was no enlargement of the gingiva. Orthodontic appliances are one of the factors that initiating gingival enlargement. Plaque increased can caused gingival enlargement. Increased pocket depth will cause plaque accumulation and this condition will continue to recur. The diagnosis of enforcement based on etiological decisions is very important in the gingival enlargement treatment requirements.
\end{abstract}

Keywords: gingival enlargement, gingivektomy, orthdontik appliances

\section{PENDAHULUAN}

Pembesaran gingiva didefenisikan sebagai suatu keadaan dimana ukuran gingiva bertambah dari normal yang dapat menimbulkan masalah estetis dan kebersihan gigi geligi ${ }^{2}$. Peningkatan ukuran gingiva merupakan gambaran umum terjadinya penyakit gingiva ${ }^{1}$. Istilah untuk kondisi tersebut adalah gingival enlargement atau gingival overgrowth ${ }^{1}$. Keadaan tersebut merupakan respon tubuh terhadap berbagai rangsangan mulai dari plak yang terinduksi sistemik, gangguan hormonal, obat yang diinduksi dan genetik ${ }^{1}$.

Pengaruh piranti orthodontik cekat terhadap kondisi jaringan periodontal secara umum adalah terdapatnya kondisi yang memungkinkan untuk terjadinya penumpukan plak. Hal ini diperberat oleh sulitnya menjaga oral hygiene yang berkaitan dengan menurunnya kesehatan periodontal pada pengguna piranti orthodontik cekat. Mekanisme terjadinya gingival enlargement pada pemakaian piranti orthodontik belum dipahami sepenuhnya, namun penelitian terdahulu menunjukkan hubungan positif antara penggunaan piranti orthodontik cekat dengan gingivitis dan gingival enlargemen. $t^{2}$

Gingival Enlargement menyebabkan lebih banyak akumulasi plak dan peradangan. Dengan demikian, kemungkinan ada transformasi dari sulkus gingiva menjadi poket periodontal. Perawatan periodontal diawali dengan initial phase therapy yang meliputi dental health education (DHE), scaling dan root planning, serta kuretase bila terdapat keradangan atau poket. Pembesaran gingiva yang tidak mengecil setelah dilakukan tahapan perawatantersebut, maka diperlukan suatu tindakan pembedahan pada gingiva. ${ }^{1,3}$

Tindakan yang dapat dilakukan pada pasien dengan gingival enlargement yaitu gingivektomi. Gingivektomi adalah prosedur eksisi gingiva/ pemotongan jaringan gingiva dengan membuang dinding lateral poket yang bertujuan untuk menghilangkan poket dan keradangan gingiva, sehingga mendapatkan gingiva yang fisiologis, fungsional dan estetik baik. Keuntungan gingivektomi adalah teknik sederhana, dapat mengeliminasi poket secara sempurna, meningkatkan aksesibilitas dan visibilitas untuk eliminasi kalkulus secara menyeluruh, morfologi gingiva dapat diprediksi sesuai keinginan. ${ }^{1,4}$

\section{KASUS}

Pasien wanita berusia 30 tahun datang ke klinik gigi dan mulut RSPTN UNUD dengan keluhan gusi depan bawah terasa mulai membesar \pm 1 tahun lalu dan tidak ada nyeri, pasien telah memakai piranti orthodontik cekat selama 2 tahun. Riwayat penyakit sistemik disangkal oleh pasien. Pasien telah melakukan scaling dan root planing (SRP) 3 miinggu yang lalu dan kuretase \pm 2 minggu yang lalu, dimana awalnya gusinya mengalami pembesaran, kemerahan, serta terdapat banyak karang gigi baik di rahang atas dan bawah. kontrol 2 minggu setelahnya kemerahan pada gusi pasien sudah berkurang namun masih terdapat gingival enlargement. Pada pemeriksaan klinis intraoral ditemukan malposisi berupa crowding gigi anterior.

Pemeriksaan Obyektif menunjukan Oral Hygiene yang baik, pembesaran gingiva pada gigi anterior bagian labial rahang bawah (gigi 33-43). Gingiva tampak membesar, padat, warna pink seperti gingiva sekitarnya, dan tepi gingiva tumpul. terdapat pseudo poket dengan rerata $6 \mathrm{~mm}$ pada regio anterior bawah. dengan Gingival Overgrowth Index 2. hal yang sama ditemukan juga pada daerah gigi 13-15 (Gambar 1 dan 2). 


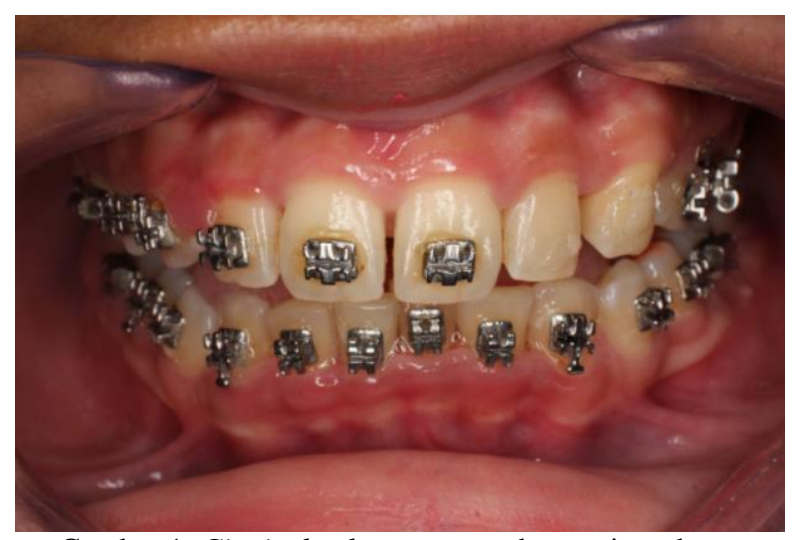

Gambar 1. Gingival enlargement pada anterior rahang bawah

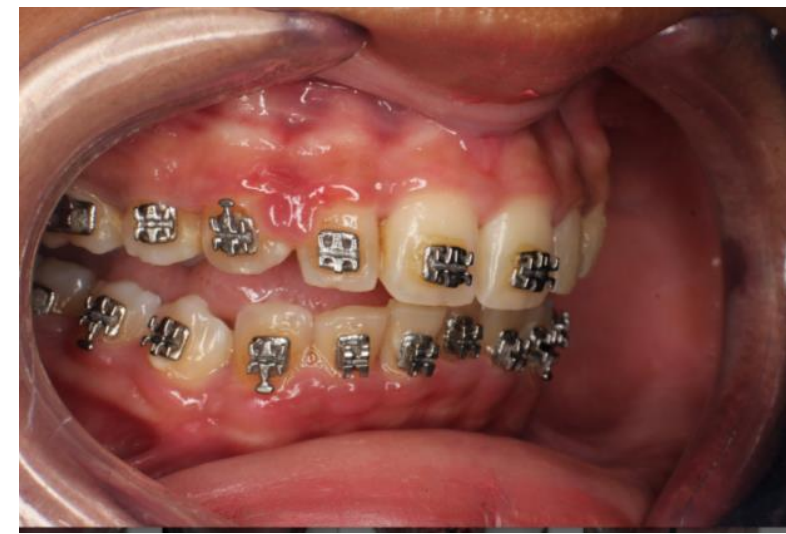

Gambar 2. Gingival enlargement pada regio kanan atas

\section{TATALAKSANA KASUS}

Perawatan dimulai setelah dilakukan pemeriksaan vital sign dan pengisian inform consent. diketahui bahwa vital sign pasien dalam batas normal. prosedur gingivektomi dimulai dengan melakukan tindakan asepsis daerah kerja dengan providon iodine. tindakan anastesi dimulai dengan aplikasi anastesi topikal, lalu anastesi infiltrasi labial dan lingual pada batas mukosa bergerak tak bergerak gigi 33-43 dengan citojet. Pembuatan bleeding point dengan pocket marking forceps dilakukan dengan cara memasukkan ujung tumpul sejajar dengan aksis gigi ke dalam poket. setelah menyentuh dasar poket, dilakukan penjepitan untuk membuat bleeding point sebagai proyeksi dari dasar poket (Gambar 3 dan 4). Insisi eksternal bevel menggunaakan blade scalpel no.15 pada posisi 1-2 mm apikal dari bleeding point membentuk sudut 45 derajat ke arah koronal untuk membentuk zero pocket. Incisi pada daerah marginal dilakukan secara continue (tidak putus-putus) dan dilanjutkan dengan incsisi daerah interdental menggunakan orban knive (Gambar 5 dan 6). Jaringan gingiva yang telah dipotong dilepaskan dengan kuret gracey. Dilakukan gingivoplasti untuk menghaluskan, menipiskan, dan mendapatkan kontur fisiologis dari gingiva dengan blade no.15. hal yang sama dilakukan pada regio 13-15. (Gambar 7). Dilakukan SRP untuk menghilangkan kalkulus yang tersisa dan dilanjutkan irigasi dengan larutan saline. aplikasi periodontal dressing (ora aid) untuk menjaga luka paska gingivektomi dari iritasi (Gambar 8). Pasien kemudian diberi medikasi amoksisilin $500 \mathrm{mg}$ tiap 8 jam untuk 5 hari dan asam mefenamat $500 \mathrm{mg}$ jika diperlukan, serta obat kumur chlorexidin $0.12 \%$ (Minosep $0,12 \%$ ). Kontrol 2 minggu tidak menunjukkan terdapatnya gingival enlargement. terdapat sedikit kemerahan pada daerah papila inter dental 31 dan 32.

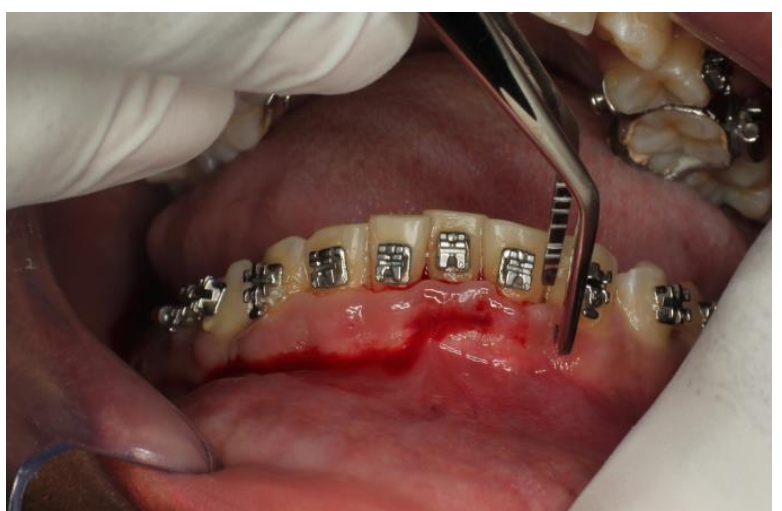

Gambar 3. Pembuatan bleeding point menggunakan poket marking forceps

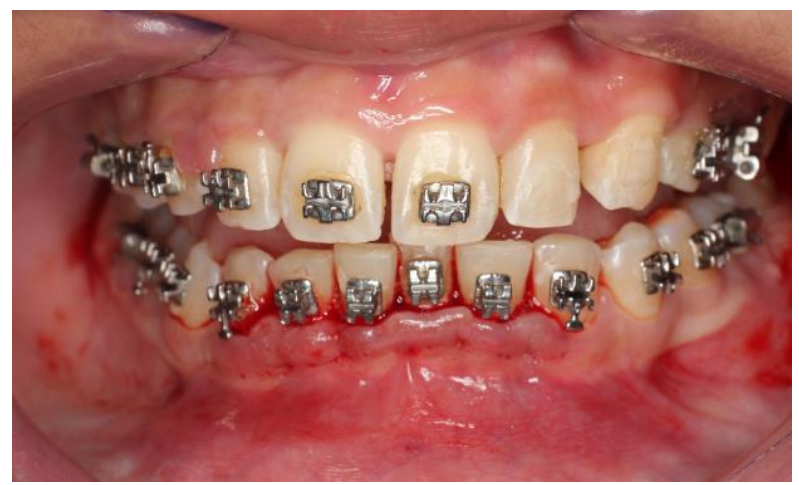

Gambar 4. Bleeding point sebagai proyeksi dasar poket

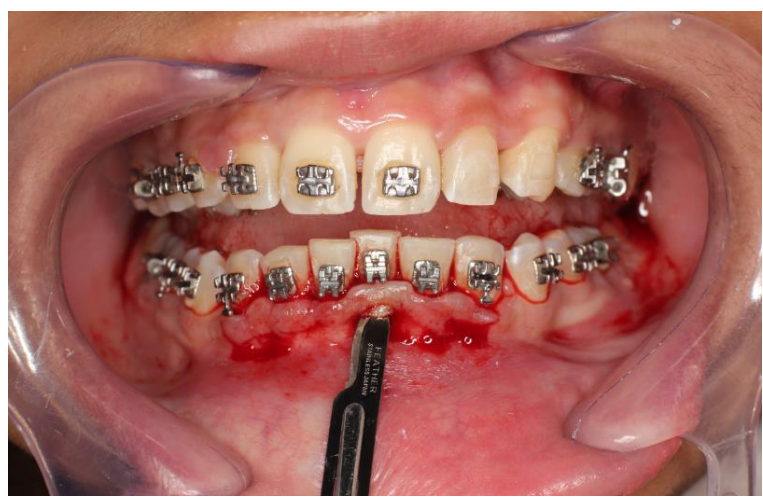

Gambar 5. Incisi internal bavel 1-2mm di apikal bleeding point

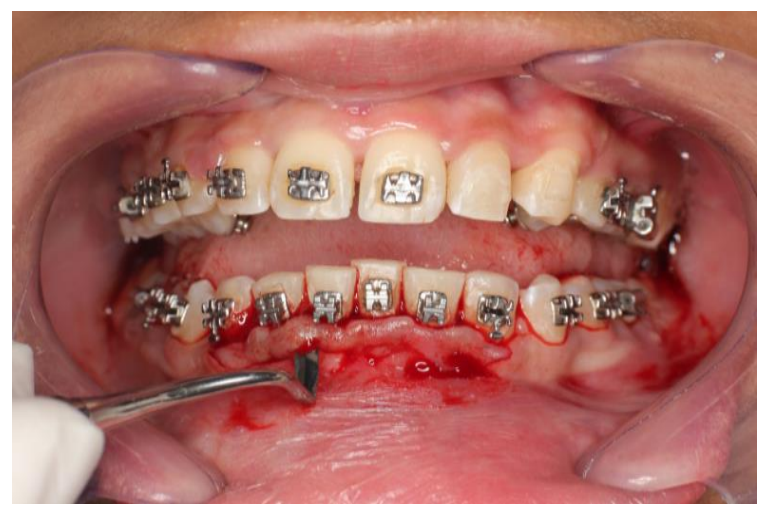

Gambar 6. Incisi pada daerah interdental menggunakan orban knive 


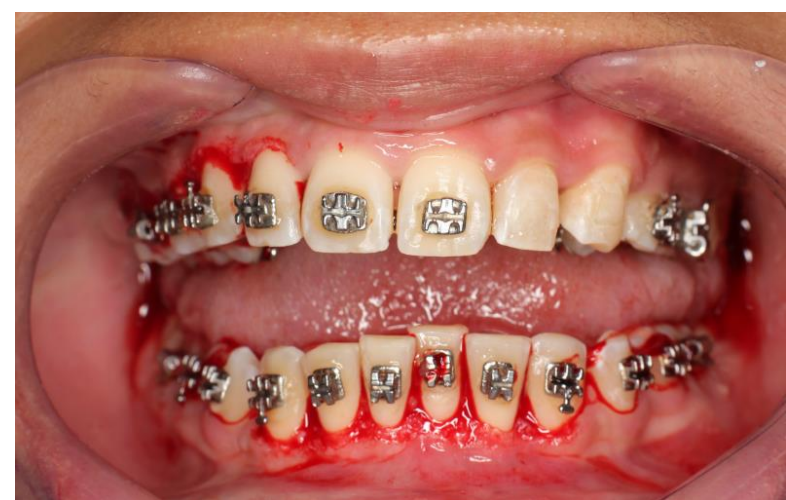

Gambar 7. Hasil gingivektomi

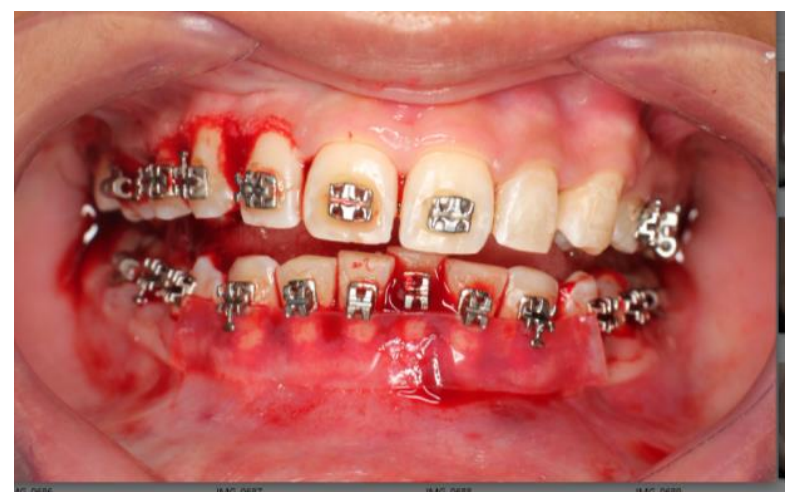

Gambar 8. Aplikasi periodontal dressing

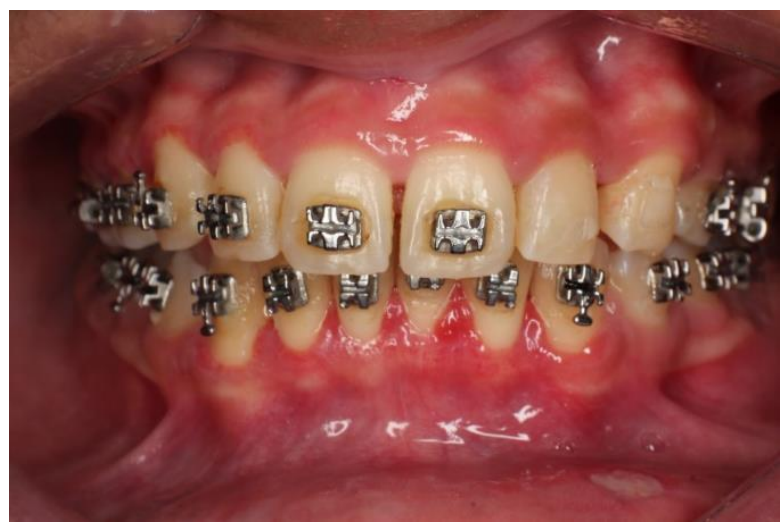

Gambar 9. Kontrol Post-Op 2 minggu

\section{PEMBAHASAN}

Gingiva enlargement adalah suatu keadaan dimana ukuran gingiva bertambah besar dari ukuran normal, sehingga selain menimbulkan masalah estetik juga dapat sebagai wadah pertumbuhan dari mikroorganisme. Jenis pembesaran gingiva ada 2 yaitu hipertrofi dan hiperplasi. Pada kasus ini terjadi hiperplasi gingiva dikarenakan pada pemeriksaan klinis ditemukan jaringan pada gingiva padat dan penuh, stippling gingiva lebih terlihat, tidak mudah berdarah, warna lebih pucat tidak seperti pada kasus hipertrofi yaitu warna gingiva lebih merah. ${ }^{3,4,5}$

Gingival enlargement timbul karena berbagai macam faktor baik lokal maupun sistemik. Dari uraian kasus diatas, disebabkan oleh faktor lokal berupa akumulasi plak dan kalkulus yang diperberat dengan malposisi gigi anterior rahang bawah, Pemakaian piranti orthodontik cekat juga merupakan salah satu faktor lokal terjadinya gingival enlargement. terdapat hubungan yang positif antara lama pemakaian piranti orthodontik cekat dengan tingkat kejadian gingval enlargement. Gingival enlargement merupakan karakteristik dari respon inflamasi tubuh terhadap produk mikrobiota pada plak. penempatan piranti orthodontik cekat akan mempermudah akumulasi dari biofilm dan colonisasi bakteri seingga akan memicu terjadinya inflamasi. Dengan adanya gingival enlargement, akan mempersulit akses ke permukaan gigi dan menyulitkan self cleansing yang mengakibatkan meningkatnya penumpukan plak. ${ }^{2}$ Hal tersebut merupakan awal mula pembesaran gingiva, namun setelah dilakukan scaling dan root planning gingiva pasien tidak kunjung menunjukkan penurunan dari ukuran ginggiva dikarenakan malposisi berupa gigi yang berjejal atau tidak teratur pada anterior rahang bawah serta kemungkinan kalkulus yang masih tertinggal pada subgingiva namun tidak terjangkau alat karena sulitnya aksesibilitas dan visibilitas sehingga diperlukan tindakan pembedahan gingivektomi dan gingivoplasti. ${ }^{3,4,5}$

Gingivektomi dan gingivoplasti merupakan perosedur bedah yang sering dilakukan bersamaan. Gingivektomi adalah prosedur eksisi gingiva/ pemotongan jaringan dimana diindikasikan untuk mengeliminasi gingival enlargement, sedangkan gingivoplasti adalah membentuk tepi gingiva sehingga tepi gingiva menjadi tajam dan sesuai dengan kontur gingiva. Prosedur gingivektomi biasanya dilakukan setelah tidak adanya penurunan ukuran gingiva setelah dilakukan scaling dan root planning, serta kuretase. ${ }^{4,6,7}$

Pada kasus ini gingival enlargement sebagai keluhan utama pasian terjadi karena adanya penumpukan plak yang dipeberat oleh pemasangan piranti orthodontik sehingga memicu terjadinya inflamasi yang terus berulang.

\section{SIMPULAN DAN SARAN}

Penentuan faktor etiologi merupakan hal yang sangat penting agar dapat menentukan tindakan yang tepat dalam penatalaksanaan gingival enlargement. gingivektomi merupakan tindakan untuk menghilangkan gingival enlargement dan untuk mempermudah pasien dalam menjaga oral hygiene diperlukan supportive periodontal therapy secara berkala untuk melihat apakah terdapat rekurensi dikemudian hari.

\section{UCAPAN TERIMA KASIH}

Penulis mengucapkan terima kasih kepada Tuhan Yang Maha Esa dan semua pihak yang telah membantu dalam tata laksana kasus sampai dengan artikel ini selesai.

\section{DAFTAR PUSTAKA}

1. Newman G. Michael, 2006, Carranza Clinical Periodontology. $11^{\text {th }}$ ed. Elsevier Saunders, California, Hal.84-95, 547-548.

2. Pinto AS, Alves LS, Zenker JE, Zanatta FB, Maltz M. Gingival enlargement in orthodontic patients: effect of treatment duration. AJO-DO. 2017; 152(4): 477-482

3. Kavitha J. Generalised gingival enlargement- a case report, International Journal of Scientific Research, 2019 vol.7, issue 10 
4. Andriani, I., 2009,Treatment Gingival Enlargement by Gingivectomy, Mutiara Medika Vol. 9 No. 1:69-73

5. Soeprapto,A., 2017, Buku Pedoman dan Tatalaksana Praktik Kedokteran Gigi, STPI Bina Insan Mulia, hal. 145- 185
6. Widagdo, AK., Murdiastuti, K., 2015, Gingivektomi Menggunakan Scalpel dan Electrocautery pada Perawatan Gingival Enlargement Wanita Pubertas, Juni 2015; 1(1): 1-4.

7. Alibasyah, ZM., 2009, Gingivektomi dan Gingivoplasti, Cakradonya Dental Jurnal, vol 1, hal 78-89. 